\title{
Beyond Human Rights: Understanding and Addressing the Attack on Public Sector Unions
}

\author{
Joseph A. McCartin
}

Published online: 29 July 2012

(C) Springer Science+Business Media B.V. 2012

In February 2011, Wisconsin Governor Scott Walker fired a salvo that continues to reverberate across the US political landscape, proposing legislation intended to strip most of his state's public workers of their power to bargain collectively over such crucial issues such as pay and benefits. Walker's act was symbolically potent because 52 years earlier Wisconsin became the first state to pass legislation extending collective bargaining to public workers, but it was also significant because the Wisconsin fight was merely the most prominent of a wave of attacks on public sector unions that followed the 2010 congressional and state elections. In Ohio, North Carolina, New Jersey, and other states, Republican governors and legislators took advantage of the fiscal strains created by the Great Recession and moved aggressively to weaken government workers' unions.

In many ways, these attacks galvanized unions and their supporters like no other event in a generation. Thousands of protestors occupied the Wisconsin state house, and although they were unsuccessful in blocking enactment of Walker's legislation, they energized a recall movement that removed key legislators who voted for the bill and forced Walker himself into a hard-fought recall election battle. In Ohio, voters went to the polls and rolled back that state's anti-union Senate Bill 5 in a referendum, restoring public workers' bargaining rights that Gov. John Kasich had tried to erase. Most interestingly, public opinion polls indicated that a majority of Americans did not approve of efforts to deal with budget deficits by destroying collective bargaining. Indeed, these fights seemed to unearth a hidden reservoir of support for collective bargaining whose dimensions surprised even labor leaders. But Scott Walker's ability to prevail handily in the recall election of June 5, 2012 showed that this one issue was simply not enough to convince voters to dump Walker. In the wake of Walker's triumph, it is clear that the fight for the future of public sector unionism is settling down in into grinding state-by-state trench warfare that is likely to extend indefinitely into the future. In these hard-fought battles, not only are the organizational resources

\footnotetext{
J. A. McCartin $(\square)$

Department of History, Georgetown University, 37th and O Streets, N.W., Washington, DC 20057, USA

e-mail: jam6@georgetown.edu
} 
of unions and their allies being put to the test, so too are their arguments. Amid these turbulent political currents, public sector unions are being pushed to consider anew how best to defend themselves and justify their continued existence in the face of critics who charge them with "bankrupting America."1

The question of how organized labor can best defend itself against increasingly well-funded and tightly coordinated anti-union attacks has attracted the attention of a range of sympathetic intellectuals. Among these, advocates who have framed their defense of union rights as a defense of human rights have played a prominent role. Most who have taken this approach, including Lance Compa and Susan Kang, have urged labor to renew the argument that workers' rights are human rights, to contend that collective bargaining is a right, not a privilege, and to employ devices such as the International Labor Organization's conventions upholding collective bargaining and the right of free association to defend government unions.

I sympathize with the views of Compa, Kang, and others who employ the language of human rights in defense of labor and I find much to admire in their arguments. However, I am skeptical about the utility of the human rights framework as a defense against the attacks currently directed at public sector unions and collective bargaining. I would argue that the history of the escalating anti-union attacks on public sector unions, the political dynamics unleashed by the Great Recession, and the broader context within which the US labor movement now finds itself all serve to highlight the limitations of human rights arguments and point to labor's need to broaden the defense of collective bargaining beyond the assertion of rights to engage fundamental issues of power, economic sustainability, and democratic governance that the language of rights cannot adequately engage.

The history of American anti-unionism which prepared the way for the current attacks on public sector unions points to one weakness of human rights appeals in the US context: American anti-unionism has a well-developed language of rights of its own, one quite capable of deflecting appeals to human rights with a sturdy assertion of individual rights. The lineage of rights-based anti-unionism is venerable; its roots stretching back to the earliest days of the American trade unionism. It has grown and adapted to unionism's growth. In recent times, this tradition has been most clearly embodied in the National Right to Work Committee. Since its founding in 1955, the National Right to Work Committee (NRTWC) has opposed "compulsory unionism," arguing that some workers in a given workplace ought not have the right to force other workers to pay dues or representation fees or to negotiate on their behalf if they do not desire it. The NRTWC has campaigned tirelessly for the passage of "right to work" laws that uphold its vision. ${ }^{2}$

It is no coincidence that the first organization founded specifically to fight to eradicate public sector unionism was a spin-off of the NRTWC. At a conference sponsored by the NRTWC in 1973, libertarian legal scholar Sylvester Petro sparked the formation of the Public Service Research Council, an organization whose stated mission was to eliminate public sector collective bargaining, which warned that it

\footnotetext{
${ }^{1}$ See for example, Daniel DiSalvo, Government Unions and the Bankrupting of America, Encounter Broadside No. 21 (New York: Encounter Books, 2011).

${ }^{2}$ Gilbert J. Gall, The Politics of Right to Work: the Labor Federations as Special Interests, 1943-1979 (New York: Greenwood Press, 1988).
} 
would lead to "union control of government" if it was not uprooted. The Public Service Research Council (PSRC) adapted the NRTWC's critique of "compulsory unionism" into an attack on "compulsory collective bargaining" in the public sector. The arguments of the PSRC played a crucial role in rallying anti-union forces during the critical years of the mid-1970s when the 1960s-spawned upsurge of government workers' unions met its first serious resistance. Since then, that organization has waned, but its arguments have not. They have been picked up by a host of new anti-union groups such as the American Legislative Exchange Council, are echoed in the writings of anti-unionists such as Charles W. Baird, and have found their way into the public pronouncements of Scott Walker, who framed his proposal that unions be forced into holding annual certification elections as a defense of workers' rights. "It's to give workers their right to choose," he explained. ${ }^{3}$

By framing its arguments this way, American anti-unionism has largely inoculated itself against appeals to human rights and to the right of free association. Each assertion of the right to form a union evokes a counter-assertion: the right not to join a union. Each appeal to workers' rights to associate for the purposes of collective bargaining is met by a counter-appeal to the individual's right not to be coerced into accepting the union's authority to negotiate on her behalf. Rights claims thus naturally beget rights counterclaims. And in these arguments, appeals to individual rights resonate at least as well as appeals to collective rights. Indeed, references to individual rights arguably enjoy a significant advantage in US political culture. ${ }^{4}$

Therefore, the notion that well-crafted appeals to human rights can effectively counter the current attacks on public sector unions strikes me as unrealistic. It seems to me that while we should of course defend the right to form a union against the all-out assault now underway, and we should employ the framework of human rights where it seems most useful, we should not expect too much from that approach. Although it provides a much-needed rebuttal to the kind of rights talk deployed by Scott Walker and his allies, the human rights-based defense of unions is ultimately incapable of breaking out of the confines of an increasingly circular argument that libertarian anti-unionists have done so much to shape.

The political dynamics unleashed by the Great Recession surfaced a second weakness in the human rights defense of public sector unions: the difficulty of translating the demand for union rights into a rebuttal of the assertion that public sector collective bargaining has created a privileged class of government workers whose health and pension benefits exceed those of most private sector workers, and whose contracts are no longer sustainable. This assertion was at the heart of the arguments made by Scott Walker and John Kasich. While Walker and Kasich overreached in ways that made their true aims of eliminating union power transparent, we should not

\footnotetext{
${ }^{3}$ On the NRTWC and the PSRC, see Joseph A. McCartin, "A Wagner Act for Public Employees: Labor's Deferred Dream and the Rise of Conservatism, 1970-76," Journal of American History 95:1 (June 2008): 123-148; on Petro, see Jean-Christian Vinel and Joseph A. McCartin, "Compulsory Unionism: Sylvester Petro and the Career of an Anti-Union Idea," in The American Right and U.S. Labor: Politics, Ideology, and Imagination, eds. Nelson Lichtenstein and Elizabeth Tandy Shermer, 226-251 (Philadelphia: University of Pennsylvania Press, 2012). For Walker quotation, see US Congress, Committee on Oversight and Government Reform, "State and Municipal Debt: Tough Choices Ahead: Panel 1," http://www.youtube.com/watch?v=6Sxt4jMvtHs.

${ }^{4}$ For a typical expression of this anti-union rights talk, see Walter Gordon Merritt, The Struggle for Industrial Liberty (New York: League for Industrial Rights, 1922).
} 
misread the backlash that arose in Ohio and Wisconsin in 2011. That backlash had more to do with what many voters perceived as the unnecessarily confrontational tactics of these governors and the ham-handed way they seized on budget deficits as a pretext to try to eviscerate their political opponents. By June 2012, voters' continuing concerns about the economy helped Walker turn back the unions' efforts to recall him.

Overall, Republican governors found that as long as they did not overplay their hands, they could make great headway by attacking unions as representing what Governor Mitch Daniels of Indiana called "a new privileged class." By adopting this approach, Governor Chris Christie of New Jersey has been among those who have gained the most traction from confrontations with public sector unions; nor are these Republican governors alone. Even Democratic governors, such as Andrew Cuomo of New York and Jerry Brown of California, have suggested that government workers' pay and benefits in their states were no longer sustainable and would need to be rolled back. In the context of the fiscal constraints facing states and households, in which there was an apparently bi-partisan consensus emerging around the notion that public workers' pay and benefits needed to be trimmed, advancing a single-minded defense of government workers' right to bargain collectively as an inalienable human right risked sending the message that unions were out only for their government employee members, the taxpayer be damned. This helps explain why the same Gallup Poll that showed respondents disapproving of Scott Walker's efforts to strip Wisconsin workers of their bargaining rights by a nearly 2-1 margin also showed that respondents believed unions of government workers were more harmful than helpful to states, why Walker prevailed in his recall election, why the overall approval rating of unions plunged during the Great Recession, and why it continues to hover near its all-time low. Simply put, the assertion of rights does not necessarily make good politics, and the defense of unions against the growing power of their opponents at this crucial juncture will require extraordinarily deft politicking. ${ }^{5}$

This brings us to the larger problem that American unions face in this century. The anti-unionism of Scott Walker and his ilk is merely a symptom of that larger problem, not its cause. Labor is struggling today with a systemic problem emerging from the transformation of the international economy, the dramatic weakening of the state as an effective regulator, and the erosion of workers' capacity to stage successful collective actions. These trends have weakened unions everywhere in the industrialized world, but nowhere have the trends been more clearly visible than in the USA, whose borders are more permeable to products, people, and capital movements than ever, whose chief agency charged with enforcing workers' rights, National Labor Relations Board, has been all but paralyzed into inactivity by deepening partisan conflict, and whose workers no longer feel that they can strike to enforce their

\footnotetext{
$\overline{{ }^{5} \text { Daniels quoted in Ben Smith }}$ and Maggie Haberman, "Pols turn on Labor Unions," June 6, 2010, http://www.politico.com/news/stories/0610/38183.html (accessed May 16, 2012); on Christie, see Daniel DiSalvo, "The Trouble with Public Sector Unions," National Affairs (Fall 2010), 18; Charles V. Bagli, "Cuomo Gains Ally for Looming Fight with the Public-Employee Unions," New York Times, December 9, 2010; poll results discussed in Dennis Couchon, "Poll: Americans Favor Union Bargaining Rights," USA Today, February 23, 2011, http:/www.usatoday.com/news/nation/2011-02-22-poll-public-unions-wisconsin_ N.htm?csp=usat.me (accessed May 16, 2012), and Jeffrey M. Jones, “Approval of Labor Unions Holds Near Its Low, at 52\%” August 31, 2011, http://www.gallup.com/poll/149279/approval-labor-unions-holdsnear-low.aspx (accessed May 16, 2012).
} 
demands. (The number of major work stoppages has fallen from an average of 352 involving 1.6 million workers per year in the 1950 s to an average of only 20 involving a mere 128,000 workers per year in the first decade of this century.) This confluence of developments has undermined private sector unions (which now represents only $6 \%$ of the private sector workers) and by doing so left public sector unions more isolated and vulnerable. The fate of public sector unions, to a large extent, will hinge on the future of unions in the private sector.

The systemic problem that besets private sector unions in turn goes far beyond employers' efforts to deny workers their fundamental right to join a union. Addressing this systemic problem will require nothing less than the erection of a new edifice of regulation, a new New Deal appropriate to the era of globalization, and a political economy that redresses the vast imbalance that has emerged in labor-management relations. The assertion that workers' rights are human rights can only take us so far in the quest to develop such a political economy. To build what we need, we will require more effective ways of arguing for unionism as essential to democracy, the common good, and social, economic, and environmental sustainability. We will need to make clear that we need unions, including unions of government workers, not only because workers should have the right to associate to advance their collective interests, but also because a democratic society requires them to associate if economic life and work are to serve the common good in ways that are truly sustainable.

We can still invoke the principles of human rights in the settings where they do the most good. But we must also look beyond these principles to address needs that are more effectively identified and articulated by the languages of human solidarity and democratic self-government than the language of rights. Thus, the present attack on public sector unions, while posing a serious threat to the future of workers, unions, and collective bargaining, also represents an urgent invitation for us to recognize and move beyond rights discourse in search for a better way to articulate the vision of a democratic and egalitarian society. 